\title{
PUNJABI JOURNALISM AND WEB TV INDUSTRY (A STUDY \\ BASED ON THE CONTENT AND VIEWERSHIP
}

\section{OF WEB CHANNEL TV PUNJAB)}

\author{
VIJAYTA TANEJA
}

Assistant Professor, Journalism and Mass Communication, Lyallpur Khalsa College, Jalandhar, Punjab, India

ABSTRACT
The web TV industry is witnessing a boom in India as it ranks in the second number in the world for the use of
the internet. It is an irrefutable fact that media technology is going through a period of rapid change. The media
audiences in the current scenario are getting multiple choices in the forms varying from folk media to traditional media
like newspapers, radio, and television and now-a-days, the online media. The fast perforation of digital applications,
providing information, entertainment and communication related content to the people are increasing their web
dependency. In such a scenario, the present study explores the content and viewership patterns of a popular Punjabi Web
channel being operated from Jalandhar, which is popularly known as the media hub of a progressive state like Punjab.
The study highlights the online preferences of people in context to the subject, viewership time, likes, dislikes, comments,
shares etc. to understand the underlying perspectives.
KEYWORDS: Punjabi Journalism, Web TV, Content \& Viewership

Received: Aug 04, 2018; Accepted: Aug 25, 2018; Published: Sep 06, 2018; Paper Id.: IJCMSOCT20183

\section{INTRODUCTION}

Since 1990s, the immense growth of television industry has led to increased competition among the major players of this industry. Further information and technology revolution boosted up the escalation of new TV channels which envisaged immense revolution in ways of transmission and opened up new avenues for the digital revolution. Negroponte (1995) rounds up the advent of digital communication as, "the emergence of digital communications has begun a process of rapid transformation of the traditional media landscape. The conversion of pictures and sounds into binary codes means that content can be compressed to the extent that it is possible to convey significantly more content to media consumers, including television viewers, within the same waveband space"[1]. Though the internet offers an option for active viewers to access their favorite TV content at flexible timings, yet it also competes with the traditional television industry in attracting the subscribers.

In India, for instance, the users of YouTube, Hot star, Voot, Amazon Prime, Netflix and other such platforms are on the rise. In other words, the online availability of the videos has been the driving factor behind the growth of internet. It has further increased he portability of a medium like television. The users access the content as per their preferences and their own choices by getting variety of available online content. The smart television sets, which work on digital television technology, which has changed the way, the signals were received by traditional television sets. According to the report of IBEF, March 2018, "The next five years will see digital technologies increase their influence across the industry, leading to a sea change in consumer behaviour across all 
segments." It further reports, "Google's video platform, YouTube plans to increase its user base in India to 400 million, as rising internet penetration in the rural areas will enable the consumers to access videos on their smartphones."[2]

In the same context, Web channels or online channels has been contemporary way to hook the audiences. Such channels offer videos on various subjects. The growths of these channels have been signalling the domination of an interactive as well as nonlinear system where consumer reserves the sole right of deciding when and what to watch. (Swedlow, 2000)[3]. Further, such services are available to the users who pay for their internet access and thereby enhance chances of exposure. (Gunter, 2010).[4]. For example, millions of such channels are available on YouTube. In Jalandhar, media hub of Punjab, there are four such prominent YouTube channels, namely Jagbani, Prime Asia, TV Punjab and Ajit Web TV. For the purpose of study, the viewership patterns and content of TV Punjab, a web channel has been chosen. This channel, started in 2017 by Vinaypal Jaid (Editor) and G. N. Panesor was started in 2017.

Besides India, where it is a web channel, the same is available on various IPTV, Cable and Satellite networks in Canada and USA, but as it is a web channel in India so it is being categorized in this category in the present study. This channel is doing wonders in Punjabi Journalism with a strong online presence on YouTube with more than 1.25 lakh subscribers (as of 28th Feb, 2018) and $65 \mathrm{~K}+$ followers. The channel has dedicated team of 22 correspondents across Punjab with its studios in Jalandhar and Chandigarh. The popular shows being broadcasted by this channel include Punjab Speaking, Anndaata, Punjab Now, Punchnama, Fashion Doze, Mere Wale Top 10 and Movie Review.

Here, the various attributes of the top ten news stories in a period of seven days starting from April 23, 2018 to April 29, 2018 have been analyzed with the help of content analysis technique. Holsti (1969) defines content analysis as any technique which makes inferences by objectively and systematically identifying specified characteristics of messages. The ten news stories have been divided into categories like social news, crime news, political, news and entertainment news for the purpose of analysis. [5]

As per socialblade.com(a website which currently collects and tracks data from 16.7+ million YouTube channels, 3.9+ million Twitter and 8.9+ million instagram accounts), the channel has got B grading (highest rating in Punjabi online media) and maintains daily average subscribers of 779 and 1,94, 941 average daily views.[6]

\section{Objectives}

The study has been carried with the following objectives:

- To understand the content related choices of popular Punjabi Web TVs.

- To study the viewership patterns of Punjabi Web Channels

- To analyze the user preferences in terms of likes, dislikes, shares, comments, watch time etc.

- To study the demographic, geographic and other characteristics of Punjabi Web TV audiences.

\section{Hypothesis}

Following are the hypotheses of the present study:

- The Punjabi web channels try to present sensational content to the audiences irrespective of the category of the news stories. 
- The number of likes exceeds the number of dislikes and comments are posted in abusive language as there is no restriction on posting such comments on these web channels.

- On an average, men spend more time on web channels than women prioritizing the politics and crime related stories more than other categories.

- It is not only Punjab or India, where the news content of these Punjabi channels is viewed with interest, but clicks involve the participation of people from other countries too.

\section{BRIEF INTRODUCTION OF THE NEWS STORIES}

The headlines of top 10 news stories are as follows:

- Dilpreet Baba's mother afraid of his encounter.

- Amina's strategy has created problems for others.

- Amarjeet's mischievous acts have started influencing Amina Bibi

- Amina Bibi has told these lies till now.

- Kiran Bala alias Amina Bibi’s mother-in-law blamed her for illicit relations with her father-in-law.

- Lover returned after meeting his girlfriend, intelligence started investigations.

- How Parents' beloved son turned into a gangster, complete story of Dilpreet Dhahan.

- Conflicts in Congress Party after Cabinet expansion

- Why Laung was whistling at Lachi?

Firstly invited, molested and then told me to tie the thread of sharing brother-sister relationship[7].

- The category of social/ socio-religious news covered five news stories, among which four relate to the story of Kiran Bala alias Amina Bibi, a widow from Punjab, who had gone to Pakistan with a religious group to visit Sikh shrines but did not return back. According to news reports, she got converted to Islam and married a Muslim person there and left her three children here in Punjab. This news story was related to society and generated interest among the viewers, who not only made a keen observation of the each and every development of the issue, but also posted their comments. Here, it is noteworthy that people expressed their anger through this platform and criticized the lady for her mi eed by using abusive language in the comments. The headlines for the news stories on this issue were:

"Amina di chaal ne beeje horan de pari kande (Amina's strategy has created problems for others)", "Amina Bibi te Amarjeet diyan harkatan da asar shuru (Amarjeet's mischevious acts have started influencing Amina Bibi)",

"Amina Bibi ne hun tak bole eh jhooth(Till now, Amina Bibi has told these lies)" and "Kiran Bala de apne sahure naal san najayaz sambandh, sass ne lgaye sansanikhez ilzaam (Kiran Bala alias Amina Bibi's mother-inlaw blamed her for illicit relations with her father-in-law)" 
Besides these news stories, another issue was related to the visit of same religious group, i.e. Amarjeet, a guy who did not return back to India with the group. Later he came back and was changing his statements regularly in an effort to misguide the government and society. The headline for this news story was, "Salma nu mil ke wapis aaya balma, khufia agencian jaanch ch jutian (Lover returned after meeting his girlfriend, intelligence started investigations.)

- The category of crime covered three news stories on Dilpreet Dhahan, a gangster who got highlighted with attempt to murder on famous Punjabi singer Parmish Verma and one news story on Chadha Sex scandal in which the lady in the video gave clarifications about her presence and blamed Chadha for forcing her against her wishes. The top story with maximum views was an interview with the mother of gangster who even appealed her son to surrender with the headline, "Dilpreet Baba's mother afraid of his encounter'. The other story related to the same issue explained the whole story of Dilpreet Dhahan that how he turned into a gangster with the headline", Maapyen da laadla kive banya gangster, Dilpreet Dhahan di poori kahaani (How Parents' beloved son turned into a gangster, complete story of Dilpreet Dhahan). The crime story Chadha viral video with the headline, Pehlan bulaya, pher gande kamm kite- Pher banvayi rakhri (Firstly invited, molested and then told me to tie the thread of sharing brother-sister relationship) also secured large number of views as it involved political slant too.

- The political news story with the headline, "Vazaarat ch vadhe to baad Congress ch ghamasaan (Conflicts in Congress Party after Cabinet expansion)" was the only political news story to secure space during the time period of study.

- The entertainment story related to the interview of Neeru Bajwa and Amberdeep Singh with headline ' Laung kyu maarda c lachi nu seetiyan( Why Laung was whistling at Lachi?' got place in the top ten news stories because of the criticism and trolling of Neeru Bajwa in this video due to her bad dressing sense.

\section{DATA ANALYSIS AND INTERPRETATION}

The data analysis, here focuses on the various trends observed, coded, tabulated and analyzed from various you tube analytics accessed from the page of this channel during the period of study. Keeping in mind the objectives of the study, tabulation of various parameters resulted in a kind of analysis as mentioned below.

Table 1: Web Details of Punjabi Online News Channels from Jalandhar (as of 29.4.18)

\begin{tabular}{|l|c|c|c|c|c|c|c|c|}
\hline & $\begin{array}{c}\text { User } \\
\text { Created }\end{array}$ & $\begin{array}{c}\text { Subscriber } \\
\text { Rank }\end{array}$ & $\begin{array}{c}\text { Video } \\
\text { View } \\
\text { Rank }\end{array}$ & $\begin{array}{c}\text { Social } \\
\text { Blade } \\
\text { Rank }\end{array}$ & Uploads & Subscribers & $\begin{array}{c}\text { Video } \\
\text { Views }\end{array}$ & Grade \\
\hline Jagbani & 2011 & 35,904 & 16,720 & 22,721 & 22,442 & $2,15,373$ & $120,547,400$ & B \\
\hline Prime Asia & 2016 & 40,962 & 55,854 & 23,604 & 2962 & $1,88,220$ & $38,221,545$ & B \\
\hline TV Punjab & 2017 & 41,137 & 40,919 & 17,591 & 3381 & $1,87,659$ & $51,790,843$ & B \\
\hline Ajit Web & 2015 & $3,24,017$ & $6,28,839$ & $4,29,917$ & 12,566 & 16,701 & $3,137,150$ & B- \\
\hline
\end{tabular}

Source: socialblade.com

The data mentioned in the Table 1, above shows the date of creation, subscriber rank, video view rank, social blade rank, and uploads subscribers, video views and grade of the online Punjabi news channels of Jalandhar as noted from socialblade.com. Though TV Punjab started working in 2017 as confirmed from its owners, the date of the creation is shown on social blade is 2013. The table further shows that though Ajit is the most read Punjabi daily of Punjab, yet it lags behind other web TV channels of Jalandhar in its social blade rank, total number of subscribers, subscriber as well as 
video-view rank. As compared to other three web TV channels of Jalandhar i.e. Jag Bani TV, TV Punjab and Prime Asia, who have been given grade B by socialblade.com, Ajit Web is the only one to receive B minus grade. As per the details available till May 4, 2018, TV Punjab has been the front runner among other Web TV channels of Jalandhar with social blade rank of 17,591. It also maintains a subscriber rank of 41,137 with 1, 87, 659 subscribers (after Jag Bani and Prime Asia) and 5, 17, 90,843 video views. In subscriber rank as well as number of subscribers, Jag Bani another prestigious Web TV from Jalandhar tops the other three. Till the date of analysis, the total number of videos' updated by TV Punjab had been 3381 in its first year, which on an average are more than average number of videos' updated per year by other web channels, i.e. Jag Bani (3206), Prime Asia (1481) but less than Ajit Web TV (4188).

Table 2: Subject-Wise Classification of Top 10 News Stories

\begin{tabular}{|l|l|}
\hline \multicolumn{1}{|c|}{ Subject } & \multicolumn{1}{c|}{$\begin{array}{c}\text { Number } \\
\text { (Percentage) }\end{array}$} \\
\hline Crime & $3(30 \%)$ \\
\hline Social/ Socio-Religious & $5(50 \%)$ \\
\hline Politics & $1(10 \%)$ \\
\hline Entertainment & $1(10 \%)$ \\
\hline
\end{tabular}

The Table 2 shows the classification of Top 10 videos of seven days on the basis of subject. It is evident from the table that social/socio-religious issues remained the choice of online viewers with $50 \%$ of top 10 news stories belonging to this category. Besides this, crime has been the most viewed news subject with $30 \%$ news stories and the percentage of political and entertainment news stories being $10 \%$ each.

Table 3: Likes/dislikes/Shares and Comments Wise Analysis of Top 10 News Stories

\begin{tabular}{|l|c|c|c|c|}
\hline & Likes & Dislikes & Shares & Comments \\
\hline \multirow{2}{*}{ Social/ Socio-Religious } & 1534 & 445 & 838 & 237 \\
& $(14.3 \%)$ & $(20.9 \%)$ & $(20 \%)$ & $(21.5 \%)$ \\
\hline \multirow{2}{*}{ Crime } & 1992 & 355 & 482 & 144 \\
& $(18.7 \%)$ & $(16.8 \%)$ & $(1.5 \%)$ & $(13 \%)$ \\
\hline \multirow{2}{*}{ Politics } & 88 & 29 & 31 & 4 \\
& $(0.8 \%)$ & $(1.4 \%)$ & $(0.7 \%)$ & $(0.4 \%)$ \\
\hline \multirow{2}{*}{ Entertainment } & 160 & 37 & 73 & 9 \\
& $(1.5 \%)$ & $(1.8 \%)$ & $(1.7 \%)$ & $(0.8 \%)$ \\
\hline
\end{tabular}

The Table 3 shows the percentage of likes, dislikes, shares and comments received for top 10 news stories during the period of study. It is clear from the above data that maximum number of likes had been received in crime stories, i.e. 1992 followed by a social / socio-religious (1534), entertainment (160) and politics (88). Contrary to these social stories, invited maximum dislikes i.e. 441 as compared to subjects of crime (355), entertainment (37) and politics (29). The content mentioned on the website of online channel brings to the fore that most of the times, a particular news story or a particular subject accounts for the more involvement for the viewers. In this study, the people seemed more interested in the story of Amina Bibi or the dressing sense of Neeru Bajwa. In both of the cases, women were meted out the abusive treatment in the comments. 
Table 4: Gender Wise Analysis of Viewership of Top 10 News Stories

\begin{tabular}{|c|c|c|c|c|c|c|c|c|c|c|}
\hline & $\mathbf{1}$ & $\mathbf{2}$ & $\mathbf{3}$ & $\mathbf{4}$ & $\mathbf{5}$ & $\mathbf{6}$ & $\mathbf{7}$ & $\mathbf{8}$ & $\mathbf{9}$ & $\mathbf{1 0}$ \\
\hline Male & $84 \%$ & $82 \%$ & $84 \%$ & $83 \%$ & $87 \%$ & $84 \%$ & $90 \%$ & $95 \%$ & $93 \%$ & $95 \%$ \\
\hline Female & $16 \%$ & $18 \%$ & $16 \%$ & $17 \%$ & $13 \%$ & $16 \%$ & $10 \%$ & $5 \%$ & $7 \%$ & $5 \%$ \\
\hline
\end{tabular}

Here the numbers from 1-10 in the Table 4 indicate the various headlines as mentioned in brief introduction of top 10 news stories

The gender wise analysis of the viewership of top 10 stories shows that the web Punjabi news channels are accessed more by male as compared to female. As data in the Table 4 shows that, $82-95 \%$ of the online viewers for the top ten news stories were male. Although, $10 \%-18 \%$ viewers of crime and social news stories were female, but percentage remained further low from $5-7 \%$, in politics and entertainment.

Table 5(a): Geography Wise Analysis of Viewership of Top 10 News Stories

\begin{tabular}{|c|c|c|c|c|c|c|c|c|c|}
\hline & $\mathbf{1}$ & $\mathbf{2}$ & $\mathbf{3}$ & $\mathbf{4}$ & $\mathbf{5}$ & $\mathbf{6}$ & $\mathbf{7}$ & $\mathbf{8}$ & $\mathbf{9}$ \\
\hline India & $78 \%$ & $50 \%$ & $43 \%$ & $61 \%$ & $57 \%$ & $62 \%$ & $75 \%$ & $48 \%$ & $18 \%$ \\
\hline USA & $3.8 \%$ & $11 \%$ & $14.1 \%$ & $6.9 \%$ & $9.3 \%$ & $6.6 \%$ & $4.6 \%$ & $18 \%$ & $9.8 \%$ \\
\hline Canada & $3.8 \%$ & $7.8 \%$ & $8.5 \%$ & $5.9 \%$ & $7.1 \%$ & $5.4 \%$ & $4.7 \%$ & $13 \%$ & $1.7 \%$ \\
\hline UK & $2.8 \%$ & $6.8 \%$ & $7.1 \%$ & $5.2 \%$ & $5.4 \%$ & $4.6 \%$ & $3.7 \%$ & $5.1 \%$ & $2.8 \%$ \\
\hline UAE & $1.8 \%$ & $4.6 \%$ & $5.7 \%$ & $5.1 \%$ & $3.9 \%$ & $4.6 \%$ & $2.1 \%$ & $3.1 \%$ & $6.4 \%$ \\
\hline
\end{tabular}

The geographical analysis of news stories as mentioned in the Table 5(a) demonstrates the countries, to which the viewers belonged. Besides India, where the major portion of viewers relates to, i.e. from 18\%-78\% for various news stories, other nations with considerable coverage were: US (3.8\%-18\%), Canada (3.8\%-13\%), UK (2.8\%-7.1\%) and $\mathrm{UAE}(1.8 \%-6.4 \%)$. This trend of maximum percentage from all these nations was somewhat reversed in story related to the interview of Neeru Bajwa and Amberdeep Singh. Here, in this case, the geographical contribution of various nations remained as shown in the table $5(\mathrm{~b})$ mentioned below

Table 5(b): Geography Wise Analysis of Viewership of Top $10^{\text {th }}$ News Story

\begin{tabular}{|l|c|}
\hline & $\mathbf{1 0}$ \\
\hline Pakistan & $75 \%$ \\
\hline India & $10 \%$ \\
\hline UAE & $5.5 \%$ \\
\hline Saudi Arabia & $5.1 \%$ \\
\hline Kuwait & $4.4 \%$ \\
\hline
\end{tabular}

Here, it is noteworthy that the maximum number of views, i.e. $75 \%$ remained from Pakistan followed by Saudi Arabia (5.1\%), Kuwait (4.4\%), India (10\%) and UAE (5.5\%). The topic of discussion, here remained the dressing sense of Neeru Bajwa in this interview. Although the language of some comments remained very abusive, but still, the maximum viewership of this news story also reflects the interest of the Pakistani people in the Punjabi film industry and its artists. Here it is worth mentioning that, some comments defended Neeru Bajwa also.

Besides, above mentioned nations, other ones which got a mention in the viewership of almost all of the selected news stories were Italy, Australia, Germany, Kuwait, New Zealand, Saudi Arabia, Spain, Bahrain, Malaysia, Philippines, France, Qatar, Greece, Hong Kong, Singapore, Portugal, Cyprus, Oman, Lebanon etc. 


\section{CONCLUSIONS}

The Punjabi web news channels are catering to the information needs of the considerable strata of the netizens. The study has explored various parameters on the basis of statistics associated with the top ten news stories of seven days. These percentages of various variables, however, have been calculated from the total number of news stories and older stories too, which got maximum clicks. The study reveals that sensationalism rules the choices of information presenters as well as information seekers. The news stories with an element of sensationalism attracted maximum attention of the viewers, be it the case of crime or social stories. One may emphasize here on the give and take relationship between media channels and their audiences. These media channels in order to have maximum clicks try to present the content which the audience likes the most and on its other side, the audiences develop their choices accordingly. Here, almost all of the stories under top ten link during the period remained sensational in one way or another.

Interactivity can be counted as an advantage for the online media as it helps the audiences to give their feedback instantly, but in the case of these channels, the audiences use this added advantage in a negative way too. It was found from the analysis of the language of the comments that audiences use abusive language by means of these comments. In almost every news story analyzed for the study, such abusive comments were posted by people. However, these media houses possess the power to remove such comments, but still the competition in terms of number in various analytics makes it necessary for these web channels to let these comments appear on their web links. No doubt, the number of likes exceeds the number of dislikes in each and every news story, but still this media gives an opportunity to audiences to express their views.

The data reveal the greater participation of males than females on this source of information. For almost all of the news stories, more than $80 \%$ of the audience comprised of males. The reason for the same could be linked to the result as it appears or it also points towards the usage of internet by females on the email accounts of their male counterparts. The viewership of Punjabi web channels in the various countries of the world as mentioned above in data interpretation. Almost all of the nations mentioned above are receiver nations where Punjabis have migrated in order to earn money. These web channels also account for clicks from neighbouring nation, Pakistan, which shows the interest of our rival neighbour in the news events of Punjab.

\section{REFERENCES}

1. Negroponte, $N$ (1995). Being Digital: The Roadmap for Survival on the Information Superhighway. London: Hodder \& Stoughton.

2. https://www.ibef.org/industry/media-entertainment-india.aspx

3. Swedlow, T. (2000). Interactive Enhanced Television: A Historical and Critical Perspective. San Francisco, CA: Swedlow. Available from http://www.itvt.com/etvwhitepaper.html

4. Gunter, B. (2010). Television versus the internet: Will TV prosper or perish as the world moves online?. Cambridge, UK: Chandos Publishing.

5. Holsti, O. R. (1969). Content analysis for the social sciences and the humanities. Washington: Addison-Wesley Pub. Co.

6. www.socialblade.com

7. www.youtube.com 
